A. Abbasov, Director, Azerbaijan Scientific-Research and Designed-Prospecting Institute of Energetics, under the "Azerenergy" JSC, Baku, Azerbaijan ORCID ID: 0000-0003-0972-1413

\title{
ELECTRICITY PRICE FORECASTING MODELS
}

\author{
Аббасов Алі Яшар огли, \\ Аиректор, Азербайджанский Научно-Исследовательский \\ и Проектно-Изыскательский Институт Энергетики при АО "Азерэнержи", Баку, Азербайджан
}

\section{МОАЕАІ ПРОГНОЗУВАННЯ ЦІНИ НА ЕАЕКТРОЕНЕРГІЮ}

New era has begun two decades ago in the most power sectors of the globe. As electricity itself shifted from being a commodity only to a competitive trading market instrument, forecasting of power load and prices started to be another important factor. With the introduction of liberal power markets, independent players like producers, operators, traders became an important factors of liberalized power markets. New era in this secotralso increased competition among companies and countries. Thus, as new players came into scene, electricity became to be a tradable product and similar to another commodities needs to account, forecast plan of electiricity brought new challenges. With its obstacles, new atmosphere of electiricity repormation brought benefits such as lower price to end users and more utilized energy systems among the countries. Different forecasting models have been developed in order to forsee future operations. Moreover, popular modelts from economics, such as game theories, cournot model, Bertrand model, nash equilibrium plays a big role in electricity price forecasting. Simulation modelts are another methods heavily used by producers, operators and power traders in market. Additionally, statistical models, such as moving averages, Root Mean Square Error, Mean Absolute Error, mean Absolute Percentage Error, Theil's inequality coefficient are frequesntly used to determine price movements of electiricity. As its broadly used in several different industries, Time Series models using historical information and adding updated information helps to model future movement of prices. This article discusses the several methods of price forecasting of electricity in liberal power markets as high volatility of the market raises a big risk for all participants. Forecasting models explains time series analysis and briefly discusses about autoregressive, moving average, autoregressive moving average, and seasonal autoregressive moving average models. Moreover, the article illustrates examples from electricity price and load forecasts and their comparisons with actual results from trades in Turkish electricity market.

Нова ера розпочалася два, десятиліття тому в більшості галузей енергетики світу. Оскільки Сама електроенергія перейшла від товару Аишедо конкурентоспроможного інструменту торгового ринку, прогнозування енергетичного навантаження та цін стали ще одним важливим фактором. 3 введенням ліберальних ринків енергї незалежні гравці, такі як виробники, оператори, торговці, стали важАивими факторами лібералізованих ринків енергї. Нова ера в цьому секторі також посилила конкуренцію між компаніями та країнами. Таким чином, коли нові гравці вийшли на сцену, електроенергія стала товаром, що торгується, і, як і інші товари, які потрібно враховувати, прогнозний план електроенергії приніс нові викАики. Зі своїми перешкодами нова атмосфера звітності про електроенергію принесла такі переваги, як нижча ціна для кінцевих споживачів та більш використовувані енергетичні системи серед країн.,Ая прогнозування майбутніх операцій було розроблено різні моделі прогнозування. Більше того, попуяярні економічні моделі, такі як теорії ігор, модель Курно, модель Бертрана, рівновага, що відіграє важливу роль у прогнозуванні цін на електроенергію. Імітаційні моделі - це ще один метод, який активно використовується виробниками, операторами та торговцями енергією на ринку. Крім того, статистичні моделі, такі як ковзні середні, середньоквадратична помилка, середня абсолютна помилка, середня абсолютна похибка увідсотках, коефіцієнт нерівності Тейла часто використовуються для визначення руху цін на електроенергію. Моделі часових рядів, які широко використовуються в декількох галузях промисловості, використовують історичну інформацію та додають оновлену інформацію, що допомагає моделювати майбутній рух цін. У цій статті розглядаються декілька методів прогнозування цін на електроенергію на ліберальних ринках електроенергії, оскільки висока волатильність ринку Створює значний ризикдАя всіх Учасників. 


\section{ЕКОНОМIЧНА НАУКА}

Моделі прогнозування пояснюють аналіз часових рядів та коротко обговорюють авторегресивні, ковзні середні, авторегресивні ковзні середні та сезонні авторегресивні ковзні середні моделі. Крім того, стаття ілюструє приклади прогнозів цін та навантаження на електроенергію та їх порівняння 3 фактичними результатами торгів на турецькому ринку електроенергї.

Key words: time series, autoregressive, moving average, autoregressive moving average, seasonal autoregressive moving average, artificial intelligence, simulation models.

Ключові слова: часові ряди, авторегресія, ковзна середня, авторегресивні ковзні середні, сезонні авторегресивні ковзні середні, штучний інтелект, імітачійні моделі.

\section{INTRODUCTION}

More and more countries have gone through market liberalization in the last two decades. In modern liberal power markets, price volatility causes higher risk to market participants. Due to a macroeconomic factors such as financial instability, economical challenges as well as market specified challenges, such as weather dependency of renewable sources, and market couplings create an extra need for accurate price forecasting. As economies of different countries warry, their methods in forecasting power prices also differ. Advancement of new technologies into production as well as new conceptual changes in this sector resulted in a separation of what has previously been a natural monopoly. The overall goal of market liberalization is to attract investors to a competitive market, to increase efficiency in production and operation and to stimulate technological advancements. All these shifts made price forecasting a vital component in any power related company's strategy. Unlike the traditional cost-based prices, today's electricity prices are the result of several market inputs. Challenge to predict prices in the market is growing and market participants constantly try to find solutions. Since electricity cannot be stored, it has to be consumed the time it has produced on an hourly basis. This paper tries to highlight the main forecasting modeling in electricity sector and their charactersitics.

\section{ELECTRICITY PRICE FORECASTING MODELS}

Before market liberalization took over, the Price forecasting of electricity is mainly based on the use of Game Theory, simulations and time series analysis. Based on game theory models such as Nash equilibrium, Cournot model and Bertrand model are used by market participants to models their strategies. Figure 1 and figure 2 shows the schematic relations of different models.

In a liberal electricity market, market clearing price is determined by the hourly bid price. Marginal pricing is applied for all suppliers. From the economics we can state that, if the market is perfectly competitive, the market

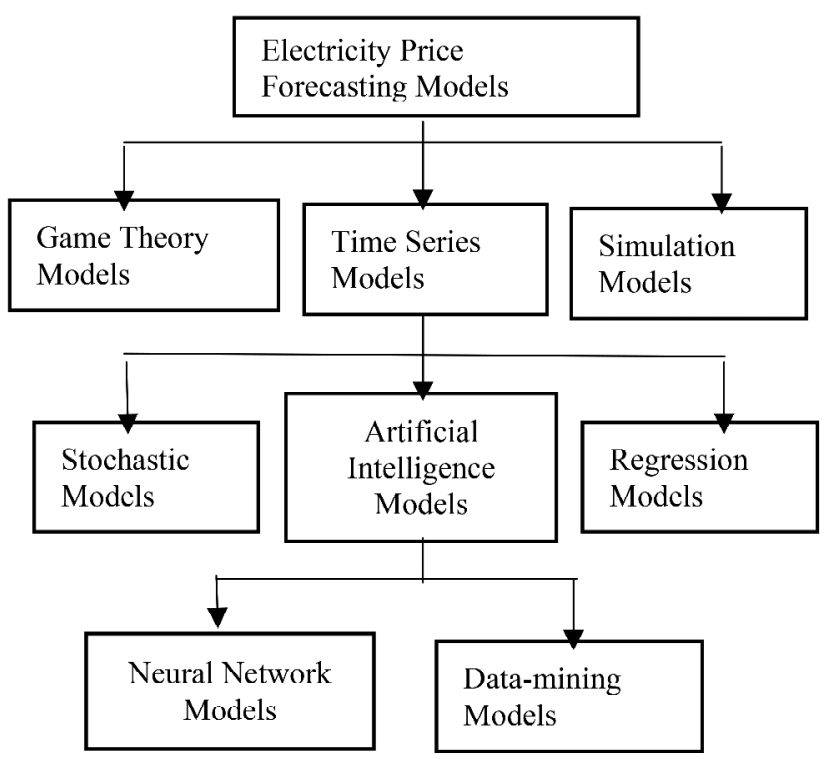

Figure 1. Electricity pricing models

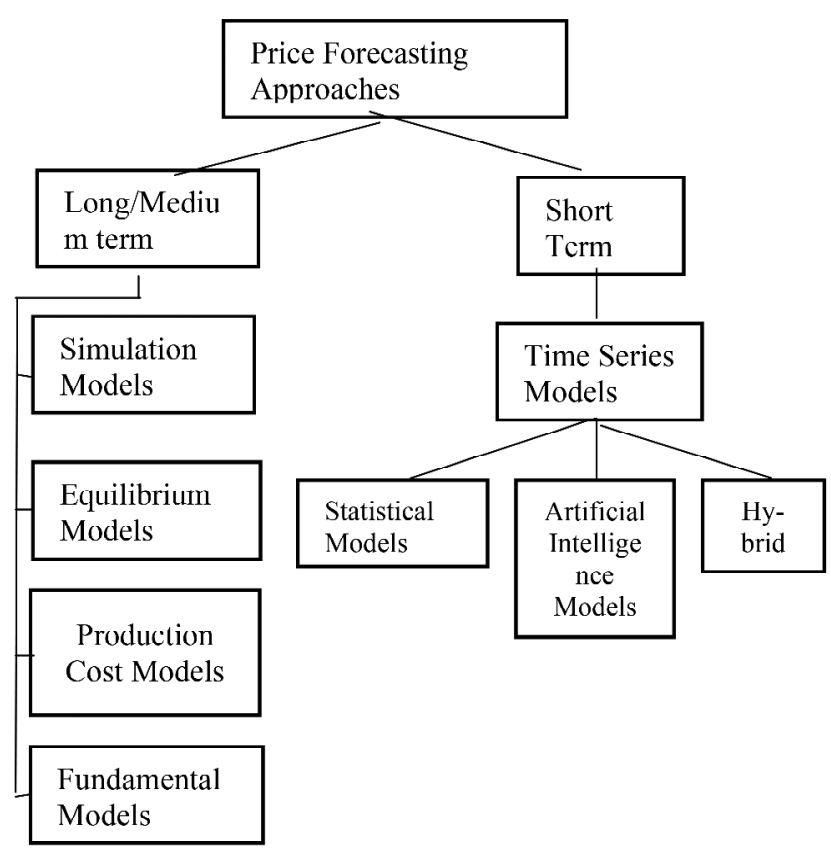

Figure 2. Price Forecasting approaches 


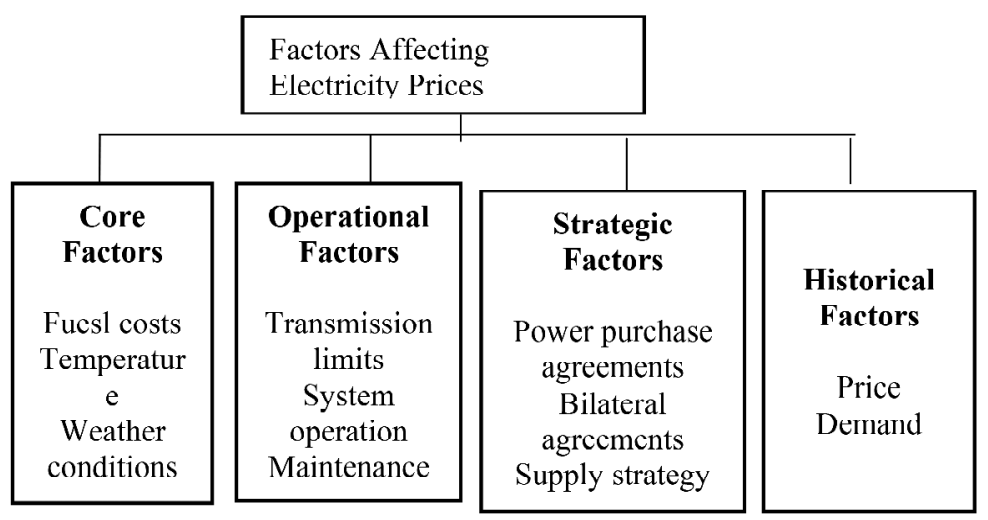

Figure 3. Factors affecting electricity price

clearing price would be equal to marginal cost of the last supplier. However, electricity markets are not perfectly competitive and customer demand is highly inelastic having few suppliers. Price forecasting in electricity can be focused on short-term (STPF), medium-term (MDPF) and long-term (LTPF). Short-term price forecasting mainly used by generation and utility companies. Sport markets create opportunity for short-term trades happen. Medium-term price forecasting usually measures the prices for several months in order to determine company strategy. Long-term price forecasting is very useful for future investment planning and measures in years [1].

Simulation models that evaluate the physical phenomena that direct a process, reaches model results by using algorithms. The main disadvantages of simulation models are its detailed requirement of information (production unit data, fuel prices, demand estimates, price bidding strategies, etc.) and calculation costs. There are major three models based on times series analysis are used in price forecasting: stochastic models, artificial neural network models, and data mining models. Autoregressive, moving average, autoregressive moving average, autoregressive conditional heteroscedasticity, generalized autoregressive conditional heteroscedasticity models are examples for stochastic models. These models can be divided into stationary and nonstationary models. In addition, time series models such as nonlinear models are used based on price fluctuations. Moreover, by adding other variables that affect the price, such as transfer function, autoregressive moving average with external variables also included in stochastic time series models.

According to the studies on price prediction of electricity, Root Mean Square Error, mean absolute error, mean absolute percent error, and Theil's inequality coefficient methods are widely used.

MSE, RMSE, MAE, MAPE are the inputs, $n$ - number of observations $\mathrm{xi}=$ Real values, $\mathrm{yi}=$ forecasted values;

$$
\text { Mean squared error }(M S E)=\frac{1}{n} \sum_{i=1}^{n}\left(y_{i}-x_{i}\right)^{2}
$$

$$
\text { Root mean squared error }(R M S E)=\sqrt{\frac{1}{n} \sum_{i=1}^{n}\left(y_{i}-x_{i}\right)^{2}}
$$

$$
\text { Mean absolute error }(M A E)=\frac{1}{n} \sum_{i=1}^{n}\left|y_{i}-x_{i}\right|
$$

Mean absolute percentage

error

$(M A P E)=\frac{100 \%}{n} \sum_{i=1}^{n}\left|\frac{y_{i}-x_{i}}{y_{i}}\right|$

\section{TIME SERIES MODELS}

Time Series analysis is a very important tool used for forecasting future prices in electricity markets. Auto- correlation and partial autocorrelation plots are intensively used in time series analysis and forecasting. Plots express graphically the comparison of time series observation with previous time results.

Forecasts based on time series analysis is derived from historical price behaviors and various external factors. Forecasting using autoregressive (AR), moving average (MA), and autoregressive moving average with (ARMA) processes is known as the Box-Jenkins method. An ARMA model, or Autoregressive Moving Average model, is used to describe weakly stationary stochastic time series in terms of two polynomials. The first of these polynomials is for autoregression, the second for the moving average.

Box-Jenkins (1976) also indicated the selection criterias. According to him, the first stage is identification (determination), the second stage is estimation, and the third stage is forward forecasting.

In the first stage, autocorelation and partial autocorrelation functions are examined for ARMA structuring by variable time graph.

Then the estimation phase is started. By estimating the coefficients at the estimation stage, the significance of the coefficients, the model coefficient of determination (R2), F-statistics, Akaike and Schwarz the appropriate model is selected. Finally, pre-reporting with the selected model (forward-looking estimate) is carried out [4].

\section{AUTOREGRESSIVE (AR) AND MOVING AVERAGE (MA)}

Autoregressive moving average (ARMA) models is very important and widely used in the modeling of time series analysis. Thus, the linear structure of ARMA helps to conduct linear prediction. ARMA model itself consist of two models: an autoregressive (AR) and moving average (MA) model. Autoregressive model predicts the next data point based on previous results using mathematical formula similar to linear regression as shown in formula 1 . The advantage of using ARMA model compared to AR or MA models is its simplicity to use with minimum required information and its efficiency in linear prediction. Autoregressive models in time series a variable such as y has its own lag values and error terms. The error term is random, zero mean and has constant variance. The error term is random, it has zero mean and has constant variance

$$
X_{t}=c+\sum_{i=1}^{p} \varphi_{i} X_{t-i}+\varepsilon_{t}
$$

$p-$ determines how many previous data points will be used;

$$
c \text { - is contant }
$$

$e$ - standard error of noise.

In the formula 2 variable y is expressed with its delayed values and error term. Autocorrelation function is calculated sample common variance divided by to sample variance. Pure AR Models - Depends on the lagged values of the data you are modeling to make forecasts. 
Table 1. Demand and price forecast of hourly electricity in Turkey

\begin{tabular}{|c|c|c|c|}
\hline \multicolumn{4}{|c|}{ Our Forecast } \\
\hline 4.5 & GP MW & GP TRY & GP USD \\
\hline 0 & 30633 & 180 & 40 \\
\hline 1 & 29878 & 174 & 39 \\
\hline 2 & 28604 & 158 & 35 \\
\hline 3 & 27616 & 150 & 33 \\
\hline 4 & 26652 & 149 & 33 \\
\hline 5 & 25315 & 148 & 33 \\
\hline 6 & 24932 & 133 & 30 \\
\hline 7 & 26196 & 155 & 34 \\
\hline 8 & 29715 & 189 & 42 \\
\hline 9 & 32139 & 198 & 44 \\
\hline 10 & 33323 & 209 & 47 \\
\hline 11 & 34121 & 211 & 47 \\
\hline 12 & 33486 & 184 & 41 \\
\hline 13 & 33822 & 191 & 42 \\
\hline 14 & 34577 & 215 & 48 \\
\hline 15 & 34311 & 210 & 47 \\
\hline 16 & 34068 & 203 & 45 \\
\hline 17 & 33353 & 181 & 40 \\
\hline 18 & 32784 & 181 & 40 \\
\hline 19 & 32831 & 158 & 35 \\
\hline 20 & 32625 & 173 & 38 \\
\hline 21 & 33243 & 178 & 40 \\
\hline 22 & 33227 & 179 & 40 \\
\hline 23 & 32026 & 156 & 35 \\
\hline$\overline{\mathrm{AVG}}$ & 31228 & 178 & 39 \\
\hline
\end{tabular}

\begin{tabular}{|c|c|c|c|}
\hline \multicolumn{4}{|c|}{ Official Results } \\
\hline 4.62 & Result MW & Result TRY & Result USD \\
\hline 0 & 31083 & 205 & 44 \\
\hline 1 & 30050 & 198 & 43 \\
\hline 2 & 29233 & 187 & 41 \\
\hline 3 & 28333 & 159 & 35 \\
\hline 4 & 27350 & 169 & 37 \\
\hline 5 & 25983 & 143 & 31 \\
\hline 6 & 25350 & 94 & 20 \\
\hline 7 & 26150 & 125 & 27 \\
\hline 8 & 29367 & 169 & 37 \\
\hline 9 & 31067 & 193 & 42 \\
\hline 10 & 31850 & 194 & 42 \\
\hline 11 & 32617 & 200 & 43 \\
\hline 12 & 31833 & 167 & 36 \\
\hline 13 & 32667 & 175 & 38 \\
\hline 14 & 33650 & 206 & 45 \\
\hline 15 & 33733 & 196 & 42 \\
\hline 16 & 33850 & 211 & 46 \\
\hline 17 & 33667 & 208 & 45 \\
\hline 18 & 33533 & 202 & 44 \\
\hline 19 & 33733 & 197 & 43 \\
\hline 20 & 33283 & 205 & 44 \\
\hline 21 & 33967 & 212 & 46 \\
\hline 22 & 33450 & 188 & 41 \\
\hline 23 & 32167 & 172 & 37 \\
\hline AVG & 31165 & 182 & 39 \\
\hline
\end{tabular}

a)

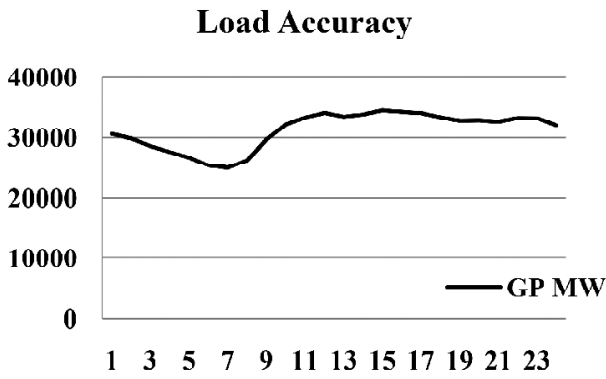

b)

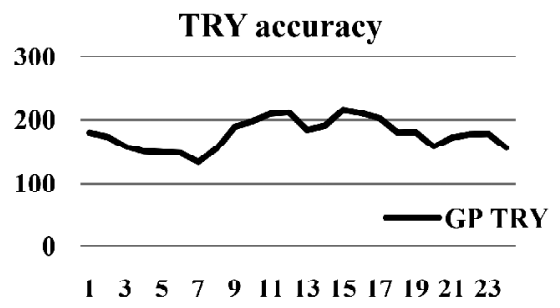

c)

USD accuracy

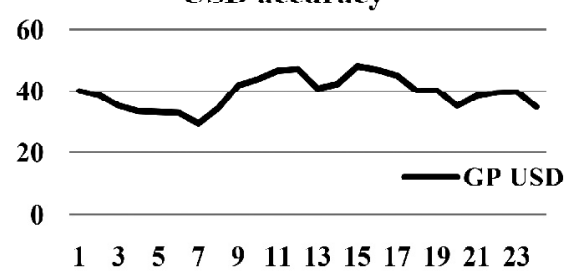

Figure 4. a - Load accuracy; b -TRY accuracy; c - USD accuracy
Moving average models explains the relationship of variable $y$ to the random movement. Depends on the errors (residuals) of the previous forecasts you made to make current forecasts.

The moving average model specifies that the output variable depends linearly on the current and various past values of a stochastic (imperfectly predictable) term. Rather than using the past values of the forecast variable in a regression, a moving average model uses past forecast errors in a regression-like model.

The primary difference between an AR and MA model is based on the correlation between time series objects at different time points. The covariance between $x(t)$ and $\mathrm{x}(\mathrm{t}-\mathrm{n})$ is zero for MA models. However, the correlation of $\mathrm{x}(\mathrm{t})$ and $\mathrm{x}(\mathrm{t}-$ n) gradually declines with $n$ becoming larger in the AR model.

This means that the moving average (MA) model does not uses the past forecasts to predict the future values whereas it uses the errors from the past forecasts. While, the autoregressive model (AR) uses the past forecasts to predict future values. As mentioned earlier, the MA model, instead of depending on the previous forecasts like in AR model, depends on the error of previous forecasts. Hence the noise quickly vanishes with time in MA model [10].

$$
\begin{aligned}
& y_{t}=c+\epsilon_{t}+\theta_{1} \epsilon_{\mathrm{t}-1}+\theta_{2} \epsilon_{\mathrm{t}-2}+. . \theta_{q} \epsilon_{\mathrm{t}-\mathrm{q}} \\
& -q \text { is the order } \\
& -c \text { is a constant } \\
& -e p s i l o n \text { is noise }
\end{aligned}
$$

\section{SEASONAL AUTOREGRESSIVE MOVING AVERAGE (SARMA)}

Seasonality in a time series analysis is a change that repeats over time period of $S$. In other words, $S$ is the number of periods from one change to another one. For instance, in electricity trading each location has its own specific characteristics, where they have high values and low values tendency in particular times.

Seasonal specified time series can be modeled with help of ARMA models. Modeling seasonal data with the ARMA model is no different from modeling non-seasonal data.

According to Box, Jenkins and Reinsel, similar to single seasoned Standard ARMA model, it can be written for seasonality, in multiple seasonal fluctuations [9].

Can be written. In other words, the ARMA model can be written both during the day and during the week including seasonal fluctuations (Taylor, 2010).

The ARMA model unlike the single seasonal component include P1 polynomial functions of order. These additional polynomial functions with ARMA models allow to model intraday fluctuations.

\section{FEATURES OF ELECTRICITY PRICES}

Today, electricity has become a commonly traded commodity in markets. The key difference of electricity from other commodities is that it cannot be stored and it has to be traded at the time produced. Due to its non-storage feature, electricity prices express certain specific characteristics such as seasonality, tendency to average price, volatility and sudden price increases.

Figure 3 illustrates the major factors affectring electricity prices. Changes in weather conditions, such as in temperature, water levels of reservoirs and changes in demand directly affect the prices. 
Above mentioned factors determine the price trends in the market and all needs to be approached for an effective forecasting. Additionally, currency rates must be projected as it plays a big role in a country where second currency involved. Figure 4 is an example from our trading electricity in Turkish market and table 1 shows our demand and price forecast in Turkish liras, price forecasts in USD as well as demand forecast and our forecast accuracy.

In above diagrams, daily clearance prices are determined using marginal costing methods. For example, EPIAS (Turkish Electricity Market Operator) receive orders and calculates 34,500 MW buy order. Market operater lines the sell orders accordingly. 9 the numbers below are for example purposes only) [2].

$1,500 \mathrm{MW}$ for $0 \mathrm{TL}$ - Wind power Plants plants

$1,000 \mathrm{MW}$ for $15 \mathrm{TL}$ - Must run (huge thermal) power

4,000 MW for $40 \mathrm{TL}$ - Run of River (they are also must run types)

14,000 MW for 70 TL - Hydro Power Plants with Dam 6,000 MW for 95 TL - Coal thermal power Plants plants

3,000 MW for $118 \mathrm{TL}$ - Imported coal/thermal power

5,000 MW for $150 \mathrm{TL}-\mathrm{Gas}$ fired power plants.

\section{CONCLUSION}

Effective price forecasting of electricity is specific to each market and it depends on variety factors, such as production capacity, demand level, seasonal effects, average production unit cost, weather condition and etc. Additionally, as electricity is a unique commodity (unlike other commodities, electricity cannot be stored, has to be consumed the time it has produced) this adds an extra volatility in prices. In modern power markets, price forecasting and its efficiency plays a big role in all market participants' strategy. All works related to power price forecasting aimed to deliver more reliable information to business units who are involved in this sector. This article mainly focused on time series analysis and its models to enlighten several factors that affect the mode and forecast and methods to use each model. There are many more models that currently being used depending on the characteristics of each market.

\section{References:}

1. Aggarwal, S. K. Saini, L. M. and ve Kumar, A. (2009), "Electricity price forecasting in deregulated markets: A review and evaluation", Electrical Power and Energy Systems, Volume 31, no. 1, pp. 13-22.

2.EPDK, (2010), "Electricity Market Report", available at: http://www.epdk.gov.tr/documents/elektrik/rapor_yayin/ElektrikPiyasasiRap oru2010.pdf (Accessed $20 \mathrm{Oct}$ 2020).

3. EPDK (2012), "Energy Investor Handbook", available at: http://www.epdk.org.tr/documents/strateji/rapor_yayin/yatirimciel_kitabi/Sgb_Rapor_Yayin_Yatirimciel_Kitabi_Tr_2012_y6Xj7FNVt7F6.pjff (Accessed 20 Oct 2020).

4. Girish, G.P. and Vijayalakshmi, S. (2013), "Determinants of Electricity Price in Competitive Power Market", International Journal of Business and Management, Vol. 8, No. 21.

5. PMUM (2013), "Day Ahead Market User Guide", Electricity Markets Operation Department, available at: https://www.pmum.gov.tr/pmumportal/belgeler/gop/ GOP KULLANICI_KILAVUZ U_v1.1.pdf (Accessed 20 Oct 2020).

6. PMUM (2014), "Day Ahead Market User Guide", Electricity Markets Operation Department, available at: https://www.pmum.gov.tr/pmumportal/belgeler/gop/ GOP_KULLANICI_KILAVUZ U_v1.1.pdf (Accessed 20 Oct 2020).

7. Kim, M.K. (2015),"Short-term price forecasting of Nordic power market by combination Levenberg-
Marquardt and Cuckoo search algorithms", IET Gener. Transm.\& Distrib., vol 9 (13), pp. 1553-1563, available at: http://mr.crossref.org/iPage?doi=10.1049\%2Fietgtd.2014.0957 (Accessed 20 Oct 2020).

8. Pagnier, L. and Jacquod, P.(2018), "How fast canon eovercome the paradox of theenergy transition? Aphysicoeconomic model for the European power grid", Energy, vol 157, pp. 550-560, available at: https://www.sciencedirect.com/science/article/abs/pii/S0360544218310296?via\%3Dihub (Accessed 20 Oct 2020).

9. Hahn, H. Meyer-Nieberg, S. and Pickl, S. (2009), "Electric load forecasting methods: Tools for decision making", Eur. J. Oper. Res., Vol 199, no. 3, pp. 902-907, available at: https://www.sciencedirect.com/science/ article/abs/pii/S0377221709002094?via\%3Dihub (Accessed 20 Oct 2020).

10. Abedinia, O. Amjady, N. and Zareipour, H. (2017), "A new feature selection technique for load and price forecast of electrical power systems", IEEE Trans. Power Syst., Vol.32, no.1, pp. 62-74, available at: https:// ieeexplore.ieee.org/document/7458187 (Accessed 20 Oct 2020).

Стаття надійшла до редакції 24.10.2020 p.

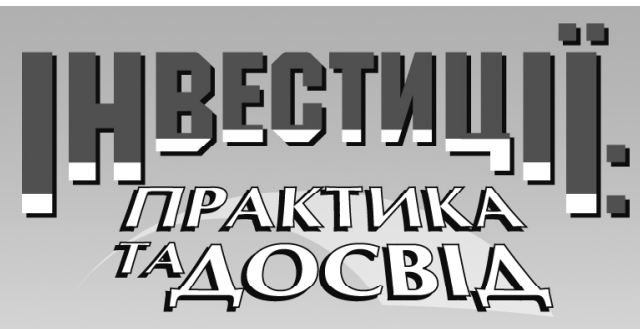

www. investplan.com.ua

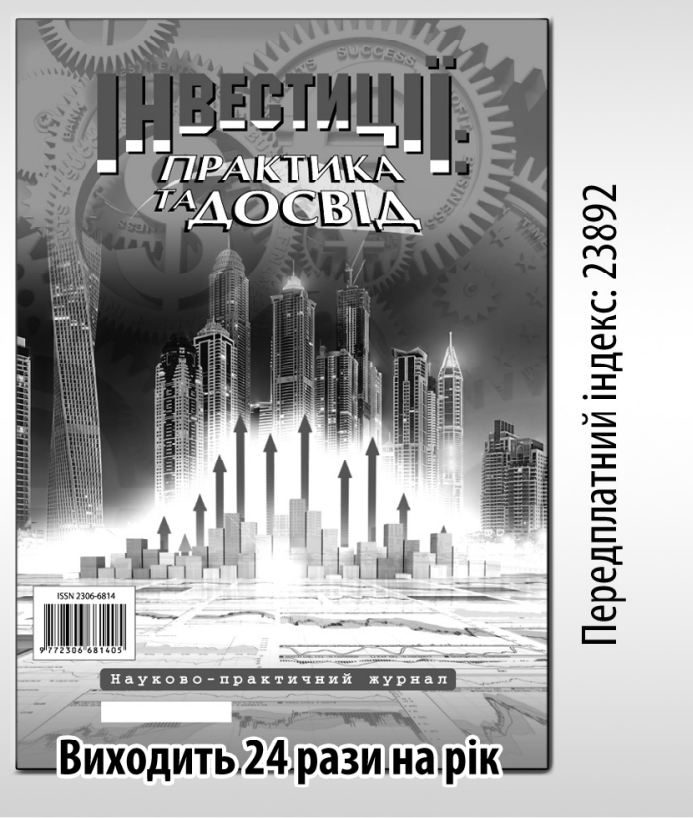

Журнал включено до переліку наукових фахових видань України (Категорія «Б») 3

\section{ЕКОНОМІЧНИХ НАУК Та ДЕРЖАВНОГО УПРАВЛІННЯ}

(Наказ Міністерства освіти і науки України № 886 від 02.07.2020)

Спеціальності - 051, 071, 072, 073, 075, 076, 281, 292 